\title{
THE ROLE OF PLS FINANCING ON ECONOMIC GROWTH: INDONESIAN CASE
}

\author{
Masrizal $^{1}$ and Budi Trianto ${ }^{2}$ \\ ${ }^{1}$ Islamic Economic Department, Faculty of Economics and Business, Universitas Airlangga, \\ Indonesia, masrizalrizal95@gmail.com \\ ${ }^{2}$ Sekolah Tinggi Ekonomi Islam (STEI) Iqra Annisa Pekanbaru, Indonesia, \\ budi_asamandiri@yahoo.com
}

\begin{abstract}
This paper investigates the role of PLS financing and non-PLS financing of Islamic banks in supporting the real sector for the case of Indonesia using monthly data from January 2009 to December 2018. Applying the ARDL approach to model their long-run and short-run relations, we find positive contribution of the PLS financing scheme to Indonesia's economic growth. Comparing the PLS and non-PLS financing, we note that the PLS financing has a larger impact on growth, both in the long run and short run. Accordingly, for Islamic finance to have larger growth impact, concrete steps and initiatives must be put in place to increase Islamic financing based on PLS arrangements.
\end{abstract}

Keyword: Islamic banking, PLS financing, Non-PLS financing, Economic growth, ARDL. JEL classification: C53; G21; G23; O47.

Article history:

Received : March 19, 2021

Revised : June 24, 2021

Accepted : : February 22, 2022

Available online : February 28, 2022

https://doi.org/10.21098/jimf.v8i1.1378 


\section{INTRODUCTION}

The Islamic financial industry has witnessed significant development especially after the 2008/2009 global financial crisis. According to the 2019 report by the Islamic Financial Service Board (IFSB), globally, the Islamic financial assets stood at USD2.190 trillion in 2018, which is accounted mostly by the GCC countries and Southeast Asian countries. Having the largest Muslim population, Indonesia is no exception to this development. While the share of Islamic financial assets is still low, Indonesia has recently made a headline in its Islamic financial development. According to the Global Islamic Finance Report 2019, Indonesia is ranked $1^{\text {st }}$ in the Islamic finance country index. Its large market size means that Islamic finance would grow further in Indonesia.

This rapid emergence of Islamic finance in particular Islamic banking has stimulated much interest and debates in its impacts on the real sector. While serving the intermediary roles, proponents of Islamic finance argue that Islamic banks bring additional benefits to the real sector. In particular, it is viewed that Islamic finance is relatively more stable than conventional finance and hence it is more capable of promoting growth and creating long-term employment (Boukhatem \& Ben Moussa, 2018). While conventional finance is plagued with agency problems, Islamic finance through equity financing and reduced risktaking mitigates information asymmetry and hence leads to lower agency costs. In addition, given that parties in the transactions bear the risk from their financial undertakings, the profit-and-loss sharing (PLS) principle of Islamic finance can mitigate moral-hazards problems through effective monitoring. The observed resilience of Islamic finance during the crisis has often been cited as a testimony that Islamic finance is amiable to economic progress. Adding to this, various recent studies have demonstrated that Islamic banking development contributes positively to economic growth (e.g., Abduh \& Azmi Omar, 2012; Kassim, 2016; Naz \& Gulzar, 2020).

Still, it should be noted that some remain skeptical whether Islamic finance will bring better benefits to the real sector than conventional finance. This skepticism stems from the fact that, in practice, the PLS financing makes up only a small percentage of total Islamic financing. In other words, as non-PLS financing dominates the financing of Islamic banks and it is generally viewed to be similar to debt-based financing of conventional banks, Islamic financing may not bring better impact to economic growth. Indeed, few studies have noted that there is no significant relationship between Islamic banking development and economic growth (Goaied \& Sassi, 2011).

Further, within the professional and academic circles, it has been strongly suggested that Islamic banks must move towards its ideal financing scheme, i.e., PLS financing. However, there is still limited evidence that PLS financing would play a better economic role. Thus, while it remains important to ascertain whether Islamic financing is good for growth, it is equally important to assess the structure of Islamic financing (PLS financing versus non-PLS financing) and its contribution to economic progress.

In light of this, the present paper investigates the roles of PLS-financing and non-PLS financing in economic development by taking Indonesia as the case study. As alluded above, the Islamic financial development in Indonesia has been 
vibrant in recent years. Islamic financing in Indonesia has been characterized not only by fast growth of its financing but also by notable increase in PLS financing. The report by the Financial Services Authority notes that, in 2019, the PLS financing scheme reached 47.3 percent. In comparison, this proportion surpasses several other countries that have both Islamic banks and conventional banks. This encouraging achievement makes Indonesia as an interesting case study, which would not only add to existing limited literature but also serve as lessons for other countries moving in the same direction.

The remainder of the paper is organized as follows. The next section reviews related literature. Then, in section III, data and empirical models are presented. Section IV provides estimation results and financings. Finally, section V concludes the paper.

\section{LITERATUR REVIEW}

The relation between finance and economic growth can be traced back to the seminal work by Schumpeter (1934). As financial intermediaries, banks play a key role in supporting economic growth via efficient allocation of financial resources, effective monitoring and risk management and lowering information costs. While Islamic banks are guided by the Shari'ah and hence are different from conventional banks, they serve these same functions. At the same, they bring additional benefits. One of the principles of Islamic banking is the principle of profit-and-loss sharing (PLS), see inter alia Qureshi (1946), Ahmad (1952), Siddiqi (1983), and Khan (1983). According to Kahf \& Khan (1992), Aggarwal \& Yousef (1996; 2000), Ahmed (2002), and El-Hawary, Grais, \& Iqbal (2006), mudhorabah and musyarakah contracts are ideal contracts in Islamic banking operations and they are ideal forms of Islamic finance intermediation, where it renders Islamic finance to be linked directly to the real sector.

The PLS scheme of Islamic Banks is arguably beneficial to the economy. In a musyarakah contract, each client (entrepreneur) will not experience any burden at the beginning of the project because each party has rights and obligations to the business it manages and share the risk in the project undertaken (Iqbal \& Mirakhor, 2007). Therefore, this scheme is an ideal way to achieve economic justice and social justice (Fianto, 2017). Zamil (2014) argues that the concept of profit and loss sharing can lead to a more efficient and optimal allocation of resources than an interest-based system. Fianto (2017) adds that the PLS Mechanism can provide the best solution to empower the poor and can turn potential capital into profit. On these bases, it is generally viewed that Islamic finance would provide a stronger support to real activities and hence economic growth.

The fast growth of Islamic banking has stimulated much discussion, particularly in its impacts on the real sector or on economic growth. From the existing literature on Islamic finance and economic growth, we may note two main but related aspects. Taking Islamic banking and finance to be different from conventional banking and finance, the first aspect extends the finance - growth nexus to Islamic finance and its impacts on economic growth. Meanwhile, noting that Islamic banking and is still far from its ideal form and hence the need to further encourage the PLS financing, the second aspect centres on the relative contribution 
of PLS and non-PLS financing to economic growth. Generally, the results from the literature seem to be more supportive of the ability of Islamic finance in promoting economic growth.

Grassa \& Gazdar (2014) examine the effect of financial development on economic growth in GCC countries. More specifically, they assess the influence of the development of Islamic finance and the development of conventional finance on economic growth for the five GCC countries (Bahrain, Kuwait, Qatar, Saudi Arabia and the UAE). The results of their study indicate that the development of conventional finance negatively and significantly affects GCC economic growth. By contrast, the development of the Islamic banking sector is a positive determinant of economic growth in the GCC countries. More interestingly, the sukuk market development does not seem to contribute to economic growth. Thus, Islamic banks emerge as a key determinant of economic growth in the GCC countries.

Yusof \& Bahlous (2013) examine the short-term and long-term relations between Islamic banking and economic growth during the 2000-2009 period in the GCC and East Asian countries. The results show that Islamic banking provides an efficient channel in linking financing to economic growth. The results also lend support to the view that Islamic intermediation does not only lead to economic benefits but also increases the entrepreneurial skills of managers through the involvement of lenders in decision-making and also reduces agency costs.

Lebdaoui \& Wild (2016) examine the relationship between Islamic banking and economic growth in Southeast Asian countries using data from 2000Q1 to 2012Q4. The results indicate that there is a long-term relationship between economic growth and Islamic banking. In addition, the share of the Muslim population plays a positive and statistically significant role in triggering the contribution of Islamic banking in the financial sector to economic growth. Abduh \& Chowdhury (2012) examine the relationship between Islamic banking and economic growth in Bangladesh from 2004Q1 to 2011Q2. Using the cointegration test method and Granger Causality, they show that Islamic banking has a positive and significant impact on economic growth both in the short and long term. This result is in line with Imam \& Kpodar (2016).

Similar results are obtained by Abduh \& Azmi Omar (2012). They examine the short- and long-term relations between the development of Islamic banks and Indonesia's economic growth from 2003: 1 to 2012: 2. Using the Autoregressive Distributed Lag (ARDL) model, they show that there is significant short-run and long-run relations between the development of Islamic finance and economic growth. They further document a two-way (bi-directional) causal nexus between them. Furqani \& Mulyany (2009), Majid \& Kassim (2015), and Kassim (2016) examine the effect of Islamic banking and economic growth in Malaysia. Their results show that developing the Islamic banking and finance industry is one of the relevant policy options to promote economic growth in Malaysia.

While all these studies have demonstrated that Islamic banking is favorable to growth, there are few studies indicating the absence of the real effects of Islamic banking development. For instance, Hachicha \& Ben Amar (2015) note that the Malaysian GDP is not very sensitive to Islamic financing in the long run. In addition, employing a panel sample of 16 countires in the Middle East and North Africa from 1962 to 2006, Goaied \& Sassi (2011) suggests no no significant relationship between the development of Islamic banking and economic growth. 
In assessing the contributions of Islamic banking to economic growth, few studies have made distinction between PLS-based financing and non-PLS-based financing. For instance, Bougatef, Nakhli, \& Mnari (2020) examine the role of Islamic Financing, PLS and Non-PLS financinf on Industrial production in Malaysia using the ARDL method. The result shows that Islamic financing plays an important role in boosting industrial production in the short and long run. Breaking the Islamic financing into its components, they note that both non-PLS financing and PLSfinancing have a positive impact on industrial production but only the former is significant. By contrast, Chowdhury, Akbar, \& Shoyeb (2018) find that the risk sharing financing is positively related to the economic growth in Bangladesh. On this basis, Chowdhury et al. (2018) argue that, for Islamic banking to have greater economic impact, the partnership contracts must be further promoted.

The present paper follows this line of research by examining the relative contributions of PLS and non-PLS financing on economic growth, where the literature is still limited. Taking Indonesia as the case for the analysis, we state the following hypotheses:

H1. Islamic financing has a positive and significant impact on economic growth in Indonesia in the short and long term

H2. PLS financing schemes have a positive and significant impact on economic growth in Indonesia in the short and long term

H3. Non-PLS financing schemes have a positive and significant impact on economic growth in Indonesia in the short and long term

H4. The PLS financing scheme has a bigger impact when compared to the non-PLS scheme on Indonesia's economic growth in the short and long term

\section{DATA AND METHODOLOGY}

\subsection{Data}

This study uses monthly data from January 2009 to December 2018. Table 1 below provides brief definition of the variables used and their data sources.

Table 1.

Variable Definition and Data Sources

\begin{tabular}{lccc}
\hline Variable & Definition & Source of Data & References \\
\hline IPI & $\begin{array}{c}\text { IPI is Industrial Production } \\
\text { Index, represents the real } \\
\text { economic sector. }\end{array}$ & $\begin{array}{c}\text { International Financial } \\
\text { Statistics (IFS)-IMF }\end{array}$ & $\begin{array}{c}\text { Kassim (2016), Bougatef et } \\
\text { al., (2020), }\end{array}$ \\
\hline FN & FN is total financing of Islamic \\
Banking & OJK & $\begin{array}{c}\text { Kassim (2016), Yusof \& } \\
\text { Bahlous (2013), Madjid \& } \\
\text { Kassim (2015), Abduh \& } \\
\text { Azmi Omar (2012), Abduh } \\
\text { \& Chouwdhury (2012) }\end{array}$ \\
\hline PLS & $\begin{array}{c}\text { PLS is profit and loss sharing, } \\
\text { the accumalation of total } \\
\text { musharakah and mudhorabah } \\
\text { financing }\end{array}$ & OJK & $\begin{array}{c}\text { Mohd Nor \& Ismail (2020), } \\
\text { Bougatef et al., (2020), } \\
\text { Chowdhury et al., (2018) }\end{array}$ \\
\hline
\end{tabular}


Table 1.

Variable Definition and Data Sources (Continued)

\begin{tabular}{lccc}
\hline Variable & Definition & Source of Data & References \\
Non-PLS & $\begin{array}{c}\text { Non-PLs is total financing } \\
\text { of murabahah, ijarah, salam, } \\
\text { istisna' etc }\end{array}$ & OJK & $\begin{array}{c}\text { Mohd Nor \& Ismail (2020), } \\
\text { Bougatef et al., (2020), } \\
\text { Chowdhury et al., (2018) }\end{array}$ \\
\hline Exp & Exp is total volume of trade & $\begin{array}{c}\text { Global Economic Monitor } \\
\text { (GEM)-World Bank. }\end{array}$ & $\begin{array}{c}\text { Yusof \& Bahlous (2013), } \\
\text { Majid \& Kassim (2015), } \\
\text { Grassa \& Gazdar (2014), } \\
\text { Mohsen, Chua, \& Sab } \\
\text { (2015) }\end{array}$ \\
\hline CPI & $\begin{array}{c}\text { CPI is Consumer Price Index, for } \\
\text { measure of inflation }\end{array}$ & $\begin{array}{c}\text { International Financial } \\
\text { Statistics (IFS)-IMF }\end{array}$ & $\begin{array}{c}\text { Majid \& Kassim (2015), } \\
\text { Kassim (2016), Lebdaoui \& } \\
\text { Wild (2016). }\end{array}$ \\
\hline
\end{tabular}

In line with Kassim (2016), we use the industrial production index (IPI) to represent real output. Our key independent variable is Islamic financing, which is represented by the total financing of Islamic banks in Indonesia and their components, namely the PLS and non-PLS financing. We define the PLS as the sum of musharakah and mudharabah financing while the rest of Islamic bank financing represents non-PLS financing (murabahah, ijarah, salam, istishna, etc.). Apart from these key variables, we also include the consumer price index (CPI) and export as controlled variable. The CPI captures inflation and hence price stability in the economy, which in turn has an impact on consumption, saving and investment decisions. The inclusion of CPI follows Kassim (2016), Lebdaoui \& Wild (2016), and Majid \& Kassim (2015). Meanwhile, exports represent the external sector, which may have impacted on the real sector (Yusof \& Bahlous, 2013; Majid \& Kassim, 2015; Grassa \& Gazdar, 2014; and Mohsen et.al, 2015). Data on Islamic finance are from the Sharia Banking statistical report (SPS) published by the Indonesian Financial Services Authority (OJK) while the data for the other variables are from the International Financial Statistics (IFS) database.

\subsection{Empirical Models}

We employ the ARDL framework to examine the long-run and short-run relations between real activity represented by the IPI and Islamic financing. As a further analysis, we also evaluate causal interactions between them by means of the TodaYamamoto causality tests.

Since our data are time series, we first subject to the Augmented Dickey-Fuller (ADF) and Philips-Perron (PP) unit root tests to establish the orders of integration. While the ARDL framework is applicable regardless of whether the variables are I(1) or (0), the tests are of utmost importance to ensure that there are no I(2) variables in the system (Ekananda, 2016). Having established the absence of I(2) variables in the model, we then proceed to the ARDL Bound testing procedure. With the presence of a long-run equation or cointegration, we then proceed to assessing the long run relations between real output and Islamic financing. To this end, we specify the following ARDL models respectively for total Islamic financing, PLS financing and non-PLS financing: 


$$
\begin{aligned}
& \ln I P I_{t}=\beta_{0}+\sum_{i=1}^{p} \beta_{1} \ln I P I_{t-i}+\sum_{i=0}^{p} \beta_{2} \ln F N_{t-i}+ \\
& \sum_{i=0}^{p} \beta_{3} \ln C P I_{t-i}+\sum_{i=0}^{p} \beta_{4} \Delta \ln E X P_{t-i}+\mu t \\
& \ln I P I_{t}=\beta_{0}+\sum_{i=1}^{p} \beta_{1} \ln I P I_{t-i}+\sum_{i=0}^{p} \beta_{2} \ln P L S_{t-i}+ \\
& \sum_{i=0}^{p} \beta_{3} \ln C P I_{t-i}+\sum_{i=0}^{p} \beta_{4} \Delta \ln E X P_{t-i}+\mu t \\
& \ln I P I_{t}=\beta_{0}+\sum_{i=1}^{p} \beta_{1} \ln I P I_{t-i}+\sum_{i=0}^{p} \beta_{2} \ln N P L S_{t-i}+ \\
& \sum_{i=0}^{p} \beta_{3} \ln C P I_{t-i}+\sum_{i=0}^{p} \beta_{4} \Delta \ln E X P_{t-i}+\mu t
\end{aligned}
$$

Where all variables are as defined in Table 1 . In the empirical implementation, we set the lag order based on the SBC criteria to ensure parsimony of the model and minimize prediction errors. From the estimation of the above ARDL models, we then compute the long run effects of each Islamic financing measure on real activity.

Apart from these long-run relations, we also examine short-run dynamics of real activity and how it is related to Islamic financing using the following errorcorrection models:

$$
\begin{aligned}
& \Delta \ln I P I_{t}=\beta_{0}+\sum_{i=1}^{p} \beta_{1} \Delta \ln I P I_{t-i}+\sum_{i=0}^{p} \beta_{2} \Delta \ln F N_{t-i}+ \\
& \sum_{i=0}^{p} \beta_{3} \Delta \ln C P I_{t-i}+\sum_{i=0}^{p} \beta_{4} \Delta \ln E X P_{t-i}+\emptyset E C T_{t-1}+\mu t \\
& \Delta \ln I P I_{t}=\beta_{0}+\sum_{i=1}^{p} \beta_{1} \Delta \ln I P I_{t-i}+\sum_{i=0}^{p} \beta_{2} \Delta \ln P L S_{t-i}+ \\
& \sum_{i=0}^{p} \beta_{3} \Delta \ln C P I_{t-i}+\sum_{i=0}^{p} \beta_{4} \Delta \ln E X P_{t-i}+\emptyset E C T_{t-1}+\mu t \\
& \Delta \ln I P I_{t}=\beta_{0}+\sum_{i=1}^{p} \beta_{1} \Delta \ln I P I_{t-i}+\sum_{i=0}^{p} \beta_{2} \Delta \ln N P L S_{t-i}+ \\
& \sum_{i=0}^{p} \beta_{3} \Delta \ln C P I_{t-i}+\sum_{i=0}^{p} \beta_{4} \Delta \ln E X P_{t-i}+\emptyset E C T_{t-1}+\mu t
\end{aligned}
$$

Finally, to investigate the causality between Industrial Production Index (IPI) and Islamic financing, we use the Toda \& Yamamoto (1995) causality test. Toda \& Yamamoto (1995) propose the causality using the VAR $\left(k+d_{\max }\right)$ models where $k$ is the optimal lag length in the original VAR system and $d_{\max }$ is the maximum order of integration of the system's variables. The VAR $\left(k+d_{\max }\right)$ model is written as:

$$
\begin{aligned}
& \Delta \ln (I P I)_{t}=\alpha+ \\
& \sum_{i=1}^{k} \beta_{1} \ln (I P I)_{t-i}+\sum_{i=1}^{k+d_{\max }} \beta_{j} \ln (I P I)_{t-j}+\sum_{i=1}^{k} \emptyset_{i} \ln (X)_{t-i}+ \\
& \sum_{j+k=1}^{k+d_{\max }} \emptyset_{j} \ln (X)_{t-j}+\delta_{1} \ln (C P I)_{t}+ \\
& \delta_{2} \ln (E X P)_{t}+\mu
\end{aligned}
$$




$$
\begin{aligned}
& \Delta \ln (X)_{t}=\gamma+ \\
& \sum_{i=1}^{k} \varphi_{1} \ln (I P I)_{t-i}+\sum_{j+k=1}^{k+d_{\max }} \varphi_{j} \ln (I P I)_{t-j}+\sum_{i=1}^{k} \omega_{i} \ln (X)_{t-i}+ \\
& \sum_{j+k=1}^{k+d_{\max }} \omega_{j} \ln (X)_{t-j}+\theta_{1} \ln (C P I)_{t}+ \\
& \theta_{2} \ln (E X P)_{t}+\pi t
\end{aligned}
$$

\section{RESULT AND DISCUSSION}

\subsection{Preliminary Tests}

We present first the preliminary tests of variables' temporal properties and their cointegration relations. As noted above, although the ARDL approach can be applied to integrated variables at I (0) or I (1), it is necessary to carry out a stationarity test to verify that there are no integrated variables at level two or I (2). Table 2 presents the results of the Augmented Dickey Fuller (ADF) and PhillipsPerron unit root tests. As may be noted from the variables, with the exception of LNFN, all variables are integrated of order 1 or I(1). For LNFN, the ADF test indicates that it is I(1) and the PP test suggests it is I(0). More importantly, we find no variable to integrated of order 2 .

Table 2.

Unit Root Tests

\begin{tabular}{lllll}
\hline \multirow{2}{*}{ Variables } & \multicolumn{3}{c}{ ADF test } & PP test \\
\cline { 2 - 5 } & Level & First difference & \multicolumn{1}{c}{ Level } & First difference \\
\hline LNIPI & -0.668166 & $-10.25744^{* * *}$ & -1.020552 & $-47.40431^{* * *}$ \\
LNFN & -1.595444 & $-3.584259^{* * *}$ & $-3.362866^{* *}$ & $-10.47422^{* * *}$ \\
LNPLS & -1.001908 & $-10.65465^{* * *}$ & -1.009446 & $-10.67318^{* * *}$ \\
LNNPLS & -0449707 & $-3.841690^{* *}$ & -0.713443 & $-10.29925^{* * *}$ \\
CPI & -2.096813 & $-8.371527^{* * *}$ & -1.868242 & $-8.654012^{* * *}$ \\
EXP & -0.646199 & $-12.05253^{* * *}$ & -0.552092 & $-12.05479^{* * *}$ \\
\hline
\end{tabular}

Note: Significant at: ${ }^{*} 10,{ }^{* * 5}$ and ${ }^{* * *} 1$ percent levels

Table 3 presents the ARDL cointegration test. The results show that there is a long-run equilibrium relationship between Islamic bank financing and the real economy.

Table 3.

ARDL Cointegration Test

\begin{tabular}{lllllll}
\hline \multicolumn{1}{c}{ MODEL } & F-Statistic Value & $\begin{array}{c}\text { Number of } \\
\text { Variables }\end{array}$ & Level significant & I(0) & I(1) \\
\hline FN & 21.10883 & 3 & $1 \%$ & 4.29 & 5.61 \\
PLS & 22.04207 & 3 & $5 \%$ & 3.23 & 4.35 \\
NPLS & 20.79884 & 3 & $10 \%$ & 2.72 & 3.77 \\
\hline
\end{tabular}

Note: The critical values are based by Pesaran, Shin, \& Smith (2001), table C (iii) unrestricted intercept and no trend 


\subsection{Long-Run Relationship}

Having established the presence of cointegration between the variables, we proceed to estimate the long run equilibrium relation between industrial production and Islamic financing by means of the ARDL procedure. Table 4 presents the estimation results. From the Table, we may note that total financing has a positive and significant relationship to real output in the long run. The estimated coefficient of total financing shows that a $1 \%$ change in Islamic financing is related to the increase in industrial production by $0.04 \%$. This result is in line with previous research conducted by Furqani \& Mulyany (2009), Majid \& Kassim (2015), Kassim (2016) for Malaysia, Abduh \& Chowdhury (2012) for Bangladesh, Lebdaoui \& Wild (2016) for Southeast Asian countries, Yusof \& Bahlous (2013) for GCC and East Asian countries, and Grassa \& Gazdar (2014) for Bahrain, Kuwait, Qatar, Saudi Arabia and the UAE.

Tabel 4.

Estimation of Long-Term Relationships

\begin{tabular}{lcccccc}
\hline \multirow{2}{*}{ Regressors } & \multirow{2}{*}{ Model FN (Model I) } & \multicolumn{2}{c}{ Model PLS (Model II) } & $\begin{array}{c}\text { Model Non-PLS (Model } \\
\text { III) }\end{array}$ \\
\cline { 2 - 7 } & Coefficients & $t$-Statistik & Coefficients & $t$-Statistik & Coefficients & $t$-Statistik \\
\hline LNFN & $0.036165^{* *}$ & 2.441503 & - & - & - & - \\
LNPLS & - & - & $0.083234^{* * *}$ & 3.694338 & - & - \\
LNNPLS & - & - & - & - & $0.025665^{* *}$ & 2.17669 \\
CPI & $0.005784^{* * *}$ & 9.337576 & $0.004064^{* * *}$ & 4.624839 & $0.006201^{* * *}$ & 12.288229 \\
LNEXP & $0.003872^{*}$ & 1.1811973 & 0.001793 & 0.893888 & $0.003892^{*}$ & 1.788746 \\
Intercept & $22.289210^{* * *}$ & 53.932322 & $21.072705^{* * *}$ & 34.985138 & $22.590082^{* * *}$ & 69.305334 \\
\hline Diagnostic test statistics & & & & & \\
\hline \multirow{2}{*}{ Serial Correlation } & & 2.179139 & & 1.304559 & & 2.383115 \\
& & $(0.3364)$ & & $(0.5209)$ & & $(0.3037)$ \\
Heteroscedasticity & 1.265873 & & 1.309518 & & 1.258163 \\
& & $(0.2811)$ & & $(0.2647)$ & & $0.2841)$ \\
D-W & 2.011165 & & 1.999117 & & 2.015222 \\
\hline
\end{tabular}

Selected Model: ARDL $(1,0,0,0)$ are selected for FN, PLS and NPLS based on Schwarz Criterion

Note: Significant at: ${ }^{*} 10, * * 5$ and ${ }^{* * *} 1$ percent levels

Our results further indicate that PLS financing and non-PLS financing have a positive and significant effect on industrial output. From the results, if there is a $1 \%$ increase in the PLS financing, the industrial production would increase by $0.08 \%$. The corresponding figure for non-PLS financing is $0.03 \%$. The results of this study also show that the effect of financing with the PLS scheme is greater than that of non-PLS financing. Thus, we collaborate the finding by Chowdhury et al., (2018) that the risk sharing scheme positively affects economic growth in Bangladesh.

This study also shows the result that the CPI variable in the three models has a positive and significant effect on industrial production in the long run. This result is in line with Majid \& Kassim (2015) for the case of Malaysia. While the EXP variable also has a positive effect on industrial production, but the significant effect is only found in models I and III. 


\subsection{Short-Run Dynamics}

Apart from the long-run equations, we also examine how Islamic financing affects the short-run dynamics of industrial production using the error correction term (ECM) model. The results are shown in Table 5. We also present the CUSUM structural stability tests for the three models, each for total financing, PLSfinancing, and non-PLS financing models in Figures 1-3. They show that the models are structurally stable.

The results of this study indicate that, in the short term, total financing has a positive and significant effect on industrial production, which is in line with Kassim (2016) for Malaysia and Abduh \& Omar (2012) in Indonesia. Further, financing under the PLS and non-PLS schemes also have a significant positive impact on industrial production. Like the long term, we also find that the PLS financing scheme has a greater impact on economic growth when compared to the non-PLS scheme. Finally, the negative and significant coefficients of the errorcorrection terms further lend support to the presence of cointegration among the variables and contributions of Islamic financing to the dynamics of industrial production. Its estimated coefficient suggests fast adjustment of the industrial production towards its long run value, where more than $90 \%$ of the previous deviation is corrected.

Table 5.

Short Term Estimation

\begin{tabular}{lcccccc}
\hline \multirow{2}{*}{ Regressors } & \multicolumn{2}{c}{$\begin{array}{c}\text { Model FN } \\
\text { (Model I) }\end{array}$} & \multicolumn{2}{c}{$\begin{array}{c}\text { Model PLS } \\
\text { (Model II) }\end{array}$} & \multicolumn{2}{c}{$\begin{array}{c}\text { Model Non-PLS } \\
\text { (Model III) }\end{array}$} \\
\cline { 2 - 7 } & Coefficients & t-Statistik & Coefficients & t-Statistik & Coefficients & t-Statistik \\
\hline LNFN & $0.030514^{* *}$ & 2.329861 & - & - & - & - \\
LNPLS & - & - & $0.072623^{* * *}$ & 3.506616 & - & - \\
LNNPLS & - & - & - & - & $0.021426^{* *}$ & 2.094308 \\
CPI & $0.004880^{* * *}$ & & $0.003546^{* * *}$ & 3.928049 & $0.005177^{* * *}$ & 6.634538 \\
LNEXP & $0.003267^{*}$ & & 0.001565 & 0.926626 & 0.003249 & $1.887914^{*}$ \\
ECM $(-1)$ & $-0.843733^{* * *}$ & -8.110590 & $-0.872518^{* * *}$ & -8.673302 & $-0.834818^{* * *}$ & -7.980042 \\
\hline
\end{tabular}

Note: ARDL $(1,0,0,0)$ are selected for FN, PLS and NPLS based on Schwarz Criterion

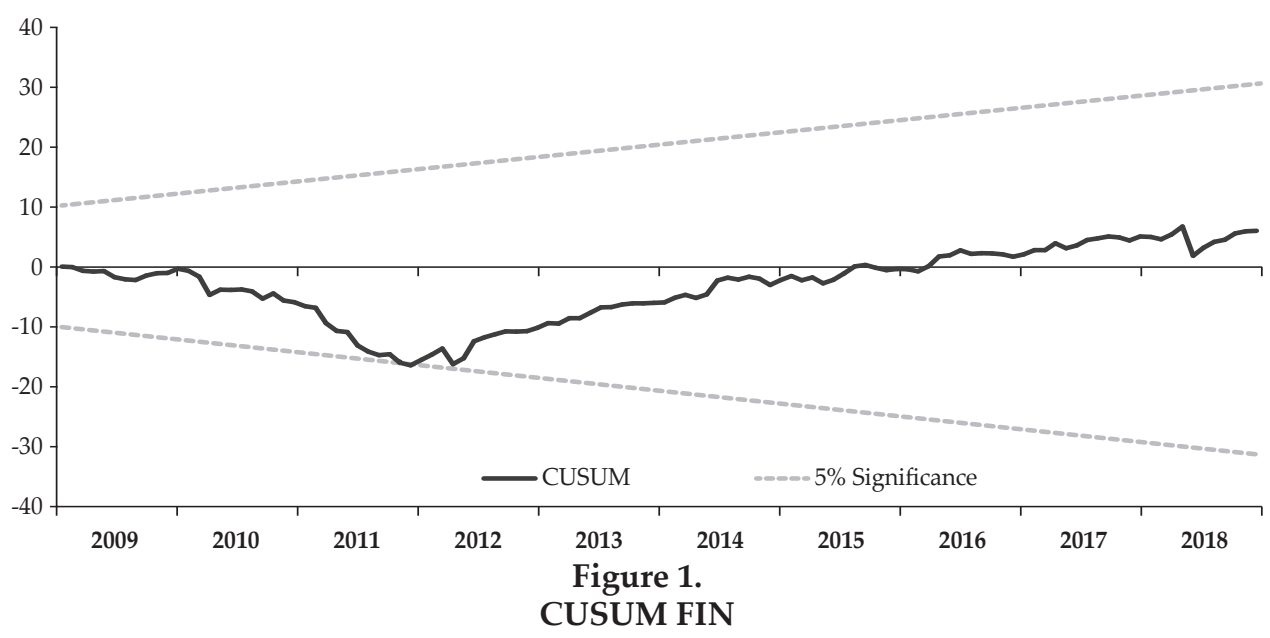



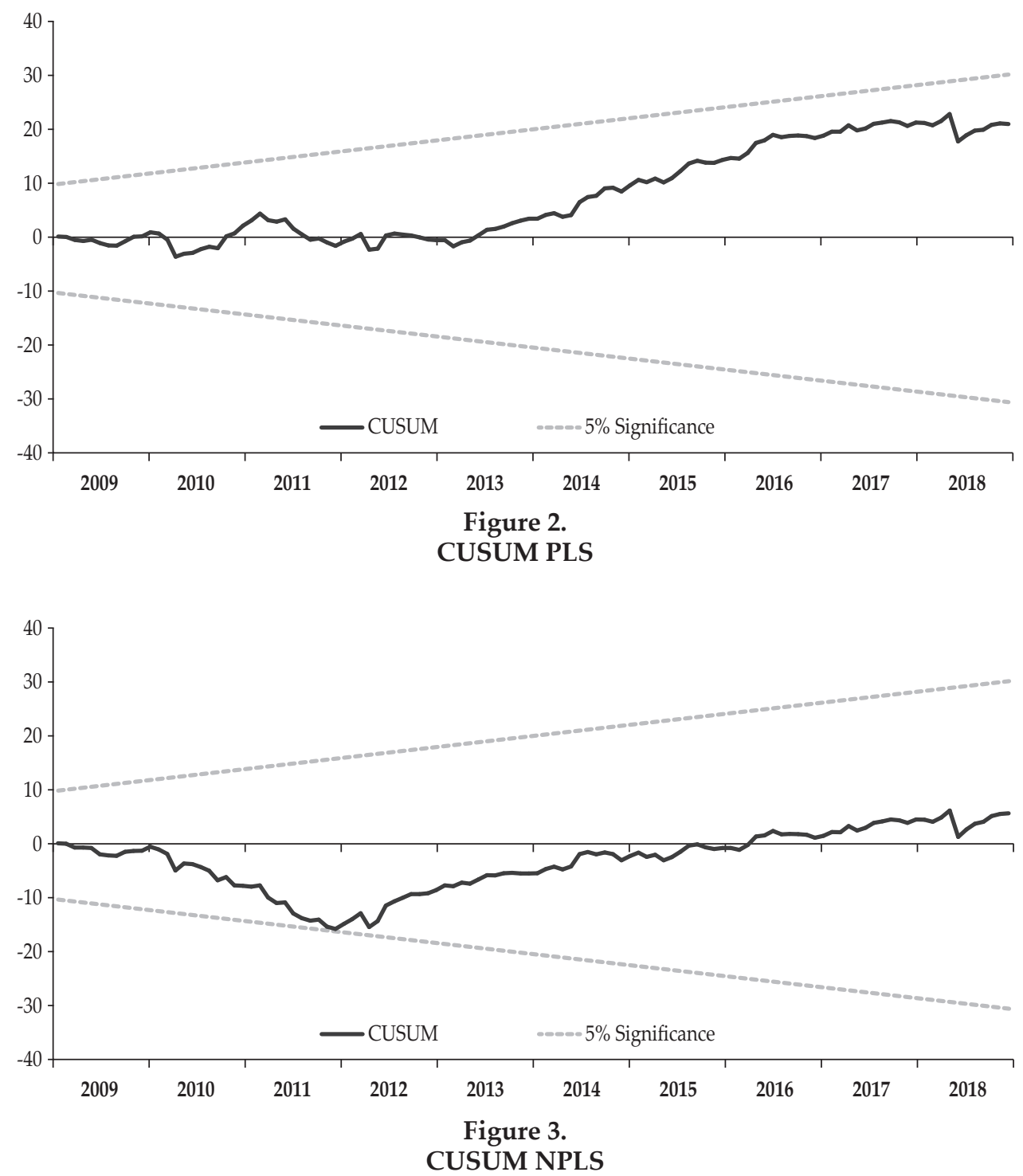

\subsection{Toda and Yamamoto Causality Test}

To detect the direction of causality between industrial production and Islamic financing, we use Toda and Yamamoto causality approach. To set the optimal lag length $k$, Akaike information criterion and SBC are used. Table 6 shows that all of the Islamic banks' financing components has unbidirectional relationship with IPI. 
Table 6.

Causality Test Results

\begin{tabular}{lcccc}
\hline Null Hypothesis & VAR & \multirow{2}{*}{$\boldsymbol{X}^{2}$} & Prob. & Direction of Causality \\
\hline FN does not granger cause IPI & 1 & 5.040473 & 0.0248 & Unbidirectional causality \\
IPI does not granger cause FN & 1 & 2.577721 & 0.1084 & \\
PLS does not granger cause IPI & 1 & 7.279866 & 0.0080 & Unbidirectional causality \\
IPI does not granger cause PLS & 1 & 1.187199 & 0.2759 & \\
Non-PLS does not granger cause IPI & 1 & 4.296630 & 0.0382 & Unbidirectional causality \\
IPI does not granger cause Non-PLS & 1 & 1.489420 & 0.2223 & \\
\hline
\end{tabular}

This empirical result shows that the causality between industrial production index and Islamic banks' financing is unbidirectional. It means that the development of Islamic finance in Indonesia leads economic growth. This finding supports the Schumpeter supply leading theory in the relationship between financial development and economic growth. In his study, Schumpeter shows that the banking system is an important factor for economic growth because of its role in saving allocation, encouraging innovation and financing productive investment (Durusu-Ciftci, Ispir \& Yetkiner, 2017). In our context, the presence of Islamic banking in Indonesia encourages growth in the real sector through various profit-sharing financing schemes. Profit sharing schemes implemented by Islamic banking will attract investors to invest in the real sector and this investment will create activities in the real sector.

In summary, this paper finds that PLS financing has better impact than nonPLS financing on economic growth in Indonesia in both the short run and long run. This indicates that the development of Islamic banking financing through the expansion of PLS financing can provides better real outcome. However, take note that, even though it has a positive and significant impact, the magnitude of its impact is still relatively small. This indicates that the contribution of Islamic banks in supporting Indonesia's economic growth is in accordance with its market share, which is $6.1 \%$. This finding provides an important note that even though the market share is still $6.1 \%$, Islamic banking in Indonesia is able to make a positive and significant contribution to Indonesia's economic growth. It means, the PLS scheme developed by Islamic banking in Indonesia is on the right track and the suggestion by Qureshi (1946), Ahmad (1952), Siddiqi (1983), and Khan (1983) to expand PLS financing.

\section{CONCLUSION AND RECOMMENDATION}

\subsection{Conclusion}

Indonesia is a country with the largest Muslim population in the world and hence has great potential for the development of Islamic finance. One of the important roles in promoting economic growth as seen from industrial production is financing from the Islamic banking sector with PLS and non-PLS schemes. This study finds that total Islamic financing has a significant positive effect on industrial production in the long and short term. Our results also indicate that the real contribution of financing using the PLS scheme is larger than tthat of the non-PLS scheme, 
both in the long and short term. These results provide direction that financing under the PLS scheme play a more significant role in economic development in countries with Islamic banking such as Indonesia. The policy implication of the results is quite obvious. Namely, for enhancing the contribution of Islamic finance on economic growth, concrete steps and initiatives must be in place to further promote PLS financing. Echoing views from professional circles, Islamic banking should move away from non-PLS financing towards PLS financing.

\section{REFERENCES}

Abduh, M., \& Azmi Omar, M. (2012). Islamic banking and economic growth: The Indonesian experience. International Journal of Islamic and Middle Eastern Finance and Management, 5(1), 35-47.

Abduh, M., \& Chowdhury, N. (2012). Does Islamic banking matter for economic growth in Bangladesh? Journal of Islamic Economics, Banking and Finance, 8(3), 104-113.

Aggarwal, R. K., \& Yousef, T. (2000). Islamic banks and investment financing. Journal of Money, Credit and Banking, 32(1), 93-120.

Aggarwal, R. K., \& Yousef, T. (1996). Islamic banks and investment financing. SSRN Electronic Journal, March(1996), 1-49. https://doi.org/10.2139/ssrn.845

Ahmad, S. M. (1952). Economics of Islam. Institute of Islamic Culture, Lahore.

Ahmed, H. (2002). A microeconomic model of an Islamic bank. Occasional Papers No. 54. The Islamic Research and Teaching Institute (IRTI), Jeddah.

Bougatef, K., Nakhli, M. S., \& Mnari, O. (2020). The Nexus between Islamic banking and industrial production, empirical evidence from Malaysia. ISRA International Journal of Islamic Finance, 12(1), 103-114.

Boukhatem, J., \& Ben Moussa, F. (2018). The effect of Islamic banks on GDP growth: Some evidence from selected MENA countries. Borsa Istanbul Review, 18(3), 231-247.

Chowdhury, M. A. F., Akbar, C. S., \& Shoyeb, M. (2018). Nexus between risk sharing vs non-risk sharing financing and economic growth of Bangladesh: ARDL bound testing and continuous wavelet transform (CWT) approach. Managerial Finance, 44(6), 739-758.

Durusu-Ciftci, D., Ispir, M. S., \& Yetkiner, H. (2017). Financial development and economic growth: Some theory and more evidence. Journal of Policy Modeling, 39(2), 290-306.

Ekananda, M. (2016). Analisis ekonometrika time series. Jakarta: Mitra Wacana Media

El-Hawary, D., Grais, W., \& Iqbal, Z. (2006). Diversity in the regulation of Islamic Financial Institutions. Quarterly Review of Economics and Finance, 46(5), 778-800.

Fianto, B. A. (2017). An empirical analysis of Islamic microfinance institutions' performance in Indonesia (pp. 1-173). New Zealand: Lincoln University. [Ph.D Thesis].

Furqani, H., \& Mulyany, R. (2009). Islamic banking and economic growth: Empirical evidence from Malaysia. Journal of Economic Cooperation and Development, 30(2), $59-74$.

GIFR. (2019). Islamic Finance Country Index - IFCI 2019. Available at: http://www. gifr.net/publications/gifr2019/ifci.pdf. Access Date: October 24 ${ }^{\text {th }}, 2020$. 
Goaied, M. \& Sassi, S. (2011). Financial development, Islamic banking and economic growth evidence from MENA region. International Journal of Business Science and Applied Management, 4(2), 105 - 128.

Grassa, R., \& Gazdar, K. (2014). Financial development and economic growth in GCC countries: A comparative study between Islamic and conventional finance. International Journal of Social Economics, 41(6), 493-514.

Hachicha, N., \& Ben Amar, A. (2015). Does Islamic bank financing contribute to economic growth? The Malaysian case. International Journal of Islamic and Middle Eastern Finance and Management, 8(3), 349-368.

IFSB. (2019). Islamic Financial Services Industry Stability Report. Malaysia: Islamic Financial Service Boards

Imam, P., \& Kpodar, K. (2016). Islamic banking: Good for growth? Economic Modelling, 59(December 2016), 387-401.

Iqbal, Z., \& Mirakhor, A. (2007). An introduction to Islamic finance, theory and practice. Solaris South Tower, Singapore: John Wiley \& Son (Asia) Pte Ltd.

Kahf, M., \& Khan, T. (1992). Principles of Islamic financing; A survey. Research Paper No. 16. Islamic Research and Training Institute, Islamic Development Bank, Jeddah.

Kassim, S. (2016). Islamic finance and economic growth: The Malaysian experience. Global Finance Journal, 30(May 2016), 66-76.

Khan, M. A. (1983). Islamic economics - Annotated sources in English and Urdu (Vol. I). Leicester, UK: The Islamic Foundation.

Lebdaoui, H., \& Wild, J. (2016). Islamic banking presence and economic growth in Southeast Asia. International Journal of Islamic and Middle Eastern Finance and Management, 9(4), 551-569.

Majid, M.S.A, \& Kassim, S. (2015). Assessing the contribution of Islamic finance to economic growth: Empirical evidence from Malaysia. Journal of Islamic Accounting and Business Research, 6(2), 292-310.

Mohd Nor, A., \& Ismail, S. (2020). Profit and loss sharing (PLS) and non-PLS financing in Malaysia: Which one should be the one? KnE Social Sciences, 4(6), 14-25.

Mohsen, A. S., Chua, S. Y., \& Sab, C. N. C. (2015). Determinants of industrial output in Syria. Journal of Economic Structures, 4(1), 19-30.

Naz, A. A. \& Gulzar, S. (2020). Impact of Islamic finance on economic growth: An empirical analysis of Muslim contries. The Singapore Economic Review, 1-12. https://doi.org/10.1142/S0217590819420062.

Pesaran, M. H., Shin, Y., \& Smith, R. J. (2001). Bounds testing approaches to the analysis of level relationships. Journal of Applied Econometrics, 16(3), 289-326.

Qureshi, A. I. (1946). Islam and theory of interest. Lahore: Syeikh M. Asyraf Publishing.

Schumpeter, J. A. (1934). Theory of economic development: An inquiry into profits, capital, credit and the business cycle. University of Illinois at Urbana-Champaign's Academy for Entrepreneurial Leadership Historical Research Reference in Entrepreneurship, Available at SSRN: https://ssrn.com/ abstract $=1496199$

Siddiqi, M. N. (1983). Issue in Islamic banking. Leichester: The Islamic Foundation.

Toda, H. Y., \& Yamamoto, T. (1995). Statistical inference in vector autoregression with possible integrated process. Journal of Econometrics, 66(1-2), 225-250. 
Yusof, R. M, \& Bahlous, M. (2013). Islamic banking and economic growth in GCC \& East Asia countries: A panel cointegration analysis. Journal of Islamic Accounting and Business Research, 4(2), 151-172.

Zamil, N. A. M. (2014). An empirical investigation into the problems and challenges facing islamic banking in Malaysia. UK: Cardiff University. [Ph.D Thesis]. 
This page is intentionally left blank 